\title{
Nilai Kearifan Lokal Folklore pada Masyarakat Kabupaten Lingga
}

\author{
Suhardi, dan Indah Puji Astuti \\ Universitas Maritim Raja Ali Haji Tanjungpinang
}

Corresponding authors.suhardi.tp@gmail.com; indah.pujiastuti26@gmail.com

How to cite this article (in APA Style). Suhardi \& Astuti, I.P. (2021). Nilai Kearifan local Folklore pada masyarakat Kabupaten Lingga. Jurnal Pendidikan Bahasa dan Sastra, 21(1), 147-156. https://doi.org/10.17509/bs_jpbsp.v21i1.36668

History of article. Received: August 2020; Revised: December 2020; Published: April 2021

\begin{abstract}
Abstrak: Ada sebuah kontradiksi yang terjadi dalam masyarakat kabupaten Lingga. Dari satu sisi masyarakatnya sangat menyadari bahwa berbagai bentuk Folklore yang ada merupakan warisan yang perlu dipertahankan dan diperkenalkan kepada generasi muda. Namun dari sisi lain, usaha untuk memperkenalkan kepada generasi mudanya tidak berjalan sesuai yang diharapkan. Generasi muda saat ini sudah banyak tidak mengenal lagi berbagai bentuk Folklore yang ada. Termasuk nilai-nilai kearifan lokalnya. Penelitian ini bertujuan untuk mendeskrisikan nilai kearifan lokalnya yang terkandung dalam Folklore masyarakat kabupaten Lingga. Metode penelitian yang peneliti gunakan adalah metode deskriptif. Sumber data adalah bentuk-bentuk Folklore masyarakat kabupaten Lingga. Teknik pengumpulan data yang digunakan adalah teknik dokumen dan wawancara. Sementara teknik analisis data menggunakan teknik analisis isi (content analysis). Hasil penelitian yang diperoleh adalah Folklore masyarakat kabupaten Lingga memiliki nilai-nilai kearifan lokal, seperti: nilai disiplin, pendidikan, gotong-royong, kedamaian, kejujuran, komitmen, peduli lingkungan, kesetiakawanan sosial, kesopansantunan, kerukunan, dan rasa syukur.
\end{abstract}

Kata kunci: nilai; kearifan local; Folklore

\section{The Value of Local Wisdom in The Folklore of Lingga District Community}

Abstract: There is a contradiction that occurs in the lingga district community. From one side of the community is well aware that various forms of Folklore that exist is a legacy that needs to be maintained and introduced to the younger generation. But on the other hand, efforts to introduce to the younger generation did not go as expected. Today's younger generation is no longer familiar with various forms of Folklore. Including the values of local wisdom. This research aims to decique the value of local wisdom contained in the Folklore of lingga district community. The research method that researchers use is descriptive method. Data sources are forms of Folklore found in lingga district communities. The data source is the Folklore forms of lingga district community. The data collection techniques used are document and interview techniques. While data analysis techniques use content analysis techniques. The results of the research obtained are Folklore lingga district community has local wisdom values, such as: disciplinary values, education, mutual assistance, peace, honesty, commitment, environmental care, social solidarity, solidarity, harmony, and gratitude.

Keywords: value; local wisdom; Folklore 


\section{Pendahuluan}

Masyarakat kabupaten Lingga sudah lama dikenal memiliki kekayaan berbagai bentuk Folklore, khususnya Folklore yang berbau kemelayuan. Folklore-Folklore tersebut diyakini kaya akan nilai-nilai kearifan lokal di dalamnya. Namun kajian terhadap berbagai bentuk Folklore yang ada tersebut sampai hari ini masih minim. Nilai-nilai kearifan lokal yang terkandung dalam berbagai bentuk Folklore yang ada masih banyak yang belum terangkat. Dengan demikian, misteri berbagai bentuk nilai kearifan lokal yang yang ada dalam Folklore Melayu masyarakat kabupaten Lingga masih sedikit diketahui. Masih banyak berbagai bentuk Folklore yang ada belum dilakukan kajian.

Ada sebuah ancaman yang terjadi saat ini terhadap berbagai bentuk Folklore yang ada. Pertama, penutur asli Folklore yang ada saat ini semakin sedikit jumlahnya. Umur mereka yang sudah semakin lanjut da nada beberapa mereka yang sudah wafat. Kedua, system pewarisan Folklore dari generasi tua kepada generasi mudah ternyata tidak berjalan sebagaimana yang diharapkan. Sebagian besar generasi muda kurang berminat untuk mewarisi berbagai bentuk Folklore yang ada. Kedua ancaman ini bila tidak cepat diatasi tentunya semakin lama bentuk Folklore yang ada semakin sedikit jumlahnya (punah).

Saat ini ada peluang besar untuk memperkenalkan berbagai bentuk Folklore yang ada kepada generasi muda. Folklore telah masuk ke dalam kurikulum jenjang pendidikan dasar, menengah, dan perguruan tinggi. Namun selama ini, selama ini belum didukung ketersediaan materi ajar yang lengkap (buku penunjang). Akibatnya, pembelajaran Folklore masih belum sesuai yang diharapkan. Oleh sebab itu, hasil kajian Folklore ini dapat menjadi alternatif, materi ajar di jenjang pendidikan dasar, menengah, dan perguruan tinggi.

Folklore merupakan kearifan lokal, yaitu pengetahuan asli (indigineous knowledge) atau kecerdasan lokal (local genius) suatu masyarakat yang berasal dari nilai luhur tradisi budaya untuk mengatur tatanan kehidupan masyarakat dalam rangka mencapai kemajuan komunitas baik dalam penciptaan kedamaian maupunpeningkatan kesejahteraan masyarakat. Kearifan lokal itu mungkin berupa pengetahuan lokal, keterampilan lokal, kecerdasan lokal, sumber daya lokal, proses sosial lokal, normaetika lokal, dan adat-istiadat lokal. Local genius, indigenious knowledge atau local wisdom dapat digali secara ilmiah dari produk kultural dengan interpretasi yang mendalam. Sebagai produk kultural, tradisi budaya seperti folklore mengandung berbagai hal yang menyangkut hidup dan kehidupan komunitas pemiliknya, misalnya sistem nilai, kepercayaan dan agama, kaidah-kaidah sosial, etos kerja, bahkan cara bagaimana dinamika sosial itu berlangsung (Pudentia, 2015)

Folklore merupakan warisan leluhur mengandung kearifan lokal (local wisdom) yang dapat dimanfaatkan dalam pemberdayaan masyarakat untuk membentuk kedamaian dan meningkatkan kesejahteraan. Kearifan lokal dalam tradisi budaya seperti folklore terbagi atas kearifan lokal yang bertujuan untuk peningkatan kesejahteraan dan yang bertujuan untuk menciptakan kedamaian. Kearifan lokal untuk kesejahteraan itu antara lain (1) kerja keras, (2) disiplin, (3) pendidikan, (4) kesehatan, (5) gotong royong, (6) pengelolaan gen-der,(7) pelestarian dan kreativitas budaya, (8) peduli lingkungan, sedangkan kearifan lokal untuk kedamaian antara lain (1) keso-pansantunan, (2) kejujuran, (3) kesetia-kawanan sosial, (4) kerukunan dan penyelesaian konflik, (5) komitmen, (6) pikiran positif, dan (7) rasa syukur. Kearifan lokal sebagai kandungan folklore itu dapat dimanfaatkan untuk pendidikan karakter generasi muda sehingga karakter itu berbasis budaya bangsa sebagai warisan leluhur. Dengan demikian, diperlukan ancangan kurikulum pendidikan karakter berbasis budaya yang bahanbahannya berasal dari folklore (Endraswara, 2011, p.20)

Dananjaya (1991) menyatakan bahwa Folklore mempunyai tiga bentuk besar, yaitu: (1) Folklore lisan, (2) Folklore 
bukan lisan, dan (3) folklore sebagian lisan. Folklore Lisan adalah folklore yang bentuknya memang murni lisan. Yang termasuk ke dalam kelompok ini adalah: a) bahasa rakyat, seperti: logat, julukan, dan sebagainyal; b) ungkapan tradisional, seperti: peribahasa, pepatah, pemeo; c) pertanyaan tradisional, seperti: teka-teki; d) puisi rakyat, seperti: pantun, gurindam, syair; e) cerita prosa, seperti: mite, legende, dongeng; dan f) nyanyian rakyat. Folklore Bukan Lisan adalah folklore yang bentuknya bukan lisan, walaupun cara pembuatannya diajarkan secara lisan. Kelompok ini dibagi menjadi dua, ialah a) material, seperti: arsitek rakyat, kerajinan tangan, pakaian, perhiasan, masakan, minumam, obat tradisi; dan b) Bukan Material, seperti: musik rakyat, gerak isyarat tradisional, bunyi isyarat komunikasi rakyat, dan sebagainya. Folklore Sebagian Lisan adalah folklore yang bentuknya merupakan campuran unsur lisan dan bukan lisan, misalnya: kepercayaan rakyat, permainan rakyat, teater, tarian, adat-istiadat, upacara, pesta, batu permata, dan sebagainya.

Berkaitan dengan kajian Folklore, terdapat beberapa penelitian yang telah dilakukan oleh peneliti lain. Pertama, Ilminisa (2016), dalam penelitiannya diperoleh data bahwa banyak nilai moral yang dapat dijadikan pelajaran dan hal tersebut terdapat dalam folklore lisan yang dimiliki oleh setiap masyarakat di wilayah tertentu. Kearifan lokal sebagai sumber untuk menanamkan pendidikan karakter dapat jauh lebih memiliki manfaat. Hal tersebut dibuktikan dengan adanya pengangkatan kearifan lokal sebagai penerapan pendidikan karakter, maka secara tidak langsung juga akan turut membantu melestarikan folklore lisan yang terdapat di wilayah-wilayah tertentu yang dijadikan lokasi pengambilan data. Kedua, penanaman pendidikan karakter yang merupakan cikal bakal seorang anak menjadi pribadi yang lebih baik dapat dibentuk dengan ceritacerita yang berkembang di masyarakat. Dari folklore lisan yang terdapat di tengah masyarakat, tentu tidak semuanya dapat dituturkan kepada anak. Orangtua harus pandai memilah dan memilih cerita mana yang seharusnya dituturkan. Hal tersebut tentu dapat didasarkan atas muatan nilai moral yang terdapat di dalamnya.

Kedua, Marwati (2015), hasil penelitiannya menginformasikan bahwa adat perkawinan masyarakat Bajo di Pulau Balu meliputi: (1) Melamar (massuro), (2) Pertemuan Tokoh Adat (pasitummuang ha'toa ada'), (3) Memanggil secara langsung (pamada'ang), (4) Peminangan (pamassuroang), (5) Pernikahan (panikka ang), (6) Mengantar Pengantin (malim-bah botteh). (ojs.uho.ac.id/index.php/HUMANIKA/arti cle/download/123456/ pd. 25 Maret 2018 09.24)

Ketiga, Angesti (2013) dalam penelitiannya diperoleh data bahwa dalam cerita rakyat Kyai Singoprono yang mempunyai 4 versi cerita, diketemukan fungsi pelaku yang paling lengkap dari 31 fungsi pelaku yang ditawarkan Vladimir Propp. Versi tersebut adalah versi ketiga yang mempunyai 26 fungsi pelaku serta 8 motif pelaku. Cerita rakyat Kyai Singoprono mengandung 17 nilai-nilai pendidikan karakter, yaitu (1) religius, (2) jujur, (3) toleransi, (4) disiplin, (5) kerja keras, (6) kreatif, (7) mandiri, (8) demokratis, (9) rasa ingin tahu, (10) semangat kebangsaan, (11) cinta tanah air, (12) menghargai prestasi, (13) bersahabat atau komunikatif, (14) cinta damai, (15) peduli lingkungan, (16) peduli sosial, dan (17) tanggung jawab. Hasil dari rekonstruksi cerita rakyat Kyai Singoprono diharapkan dapat dijadikan sebagai alternatif bahan ajar membaca teks sastra, tidak hanya pada aspek membaca, akan tetapi diharapkan dapat dijadikan sebagai alternatif bahan ajar pada semua aspek dalam pembelajaran bahasa Jawa di SMP.

Keempat, Rachman (2012), hasil penelitiannya menunjukkan bahwa cerita mengenai kisah asal usul Ki Ageng Gribig memiliki dua versi yang masingmasing dapat dipertanggung jawab- kan. Menurut versi yang pertama, Ki Ageng Gribig adalah utusan dari kerajaan Mataram pada zaman kekuasaan Sultan Agung Hanyokro Kusuma 
pada tahun 1625. Ki Ageng Gribig bisa sampai di Malang tidak dengan tanpa tujuan, beliau diutus oleh raja untuk melakukan program Mataramisasi, yakni program perluasan daerah kekuasaan kerajaan Mataram. sedangkan versi kedua, Ki Ageng Gribig merupakan utusan dari Kerajaan Blambangan Kulon yang pada zaman itu dikuasai oleh Aryo Menak Koncar. Ki Ageng Gribig bisa sampai di kota Malang juga karena mengemban tugas untuk melakukan ekspansi Blambangan, yakni bertugas melakukan perluasan daerah kekuasaan kerajaan Blambangan.

Kelima, Nursa'ah (2014) yang hasil penelitiannya menghimpun data berupa transkrip wacana cerita rakyat di Kabupaten Banjarnegara dalam bentuk tulisan berbahasa Jawa dengan dialek lokal Banjarnegara yang mencakup cerita Mulabukane Kabupaten Banjarnegara, Raden Sam Hoong, Dumadine Desa Sigaluh, Demang Tirtayasa lan Dumadine Desa-desa nang Kecamatan Purwareja Klampok, Mulabukane Batur, dan Dumadine Desa Banjarmang.

Keenam, Sukmawan dan Nurmansyah (2012), dalam penelitiannya diperoleh data bahwa manusia mengembangkan diri dan mempertahankan kehidupannya sejalan dengan sifat alamiahnya sebagai makhluk alam. Hal ini membangun kesadaran bahwa tidak ada pemisahan ontologis secara diametral antara manusia dan semesta di luarnya. Karena manusia yang partikular berlangsung dalam kesatuan dengan semesta yang universal dan semesta yang universal maujud dalam manusia yang partikular. Manusia Tengger memandang diri mereka sebagai bagian dan perpanjangan tangan dari ekosistem seluruhnya yang sejalan dengan pandangan mikrokosmos dan makrokosmos ke-Jawa-an mereka. Mereka tahu cara mengakui dan menghargai keanekaragaman dan kompleksitas ekologis Tengger dalam suatu hubungan simbiosis yang harmonis. Semua itu terpotret secara potensial dalam folklore yang mengandung nilai kearifan ekologis.
Ketujuh, Suhardi (2017) yang hasil penelitiannya diperoleh data berupa nilainilai budaya yang terkandung dalam sastra lisan masyarakat Kota Tanjungpinang meliputi: nilai religius, disiplin, kerja keras, cinta damai, lingkungan, sosial, dan nilai budaya tanggung jawab.

Kedelapan, Suhardi (2019) yang dalam penelitiannya diperoleh data bahwa masyarakat Melayu kabupaten Bintan memiliki beberapa bentuk Folklore, mulai yang berbentuk lisan, bukan lisan, hingga yang setengah lisan. Selain itu, FolkloreFolklore tersebut sangat kaya dengan nilainilai kearifan local di dalamnya. Nilai-nilai tersebut mencakup: (1) nilai keagamaan (Islam), (2) nilai budi-pekerti, (3) nilai social, (4) nilai kerja keras, dan (5) nilai pendidikan. Kelima nilai tersebut tentunya sangat berguna untuk dijadikan pedoman hidup, khususnya bagi generasi muda Melayu hari ini dan di masa depan.

Sekaitan dengan pemaparan di atas, penelitian ini bertujuan untuk mendeskrisikan nilai kearifan lokal yang terkandung dalam Folklore pada masyarakat kabupaten Lingga. Dalam penelitian ini, peneliti berupaya memperoleh data perihal materi dan sumber dari Folklore itu sendiri.

\section{Metode}

Jenis penelitian yang peneliti lakukan ini adalah penelitian yang berjeniskan penelitian kualitatif konseptual. Dengan model analisis datanya menggunakan bentuk analisis konten. Model analisis konten merupakan model analisis yang bertujuan untuk mengungkap, memahami, dan menangkap pesan yang terdapat dalam karya sastra (Endraswara, 2011). Penelitian analisis konten dalam bidang sastra berangkat dari aksioma bahwa penulis ingin mengungkapkan pesan secara sembunyi kepada pembacanya. Pesan itu berupa makna atau isi yang harus dilacak oleh pembaca. Penelitian analisis konten bertujuan untuk mengungkap dan memahami fenomena sastra, khususnya symbol sastra. Hal ini disebabkan karena setiap penggunaan bahasa oleh sastrawan 
sebenarnya memuat symbol dan makna (Endraswara, 2011).

Yang menjadi objek penelitian ini adalah bentuk-bentuk Folklore yang terdapat dalam masyarakat kabupaten Lingga. Baik yang berbentuk lisan, bukan lisan, maupun sebagian lisan. Folklore Lisan adalah folklore yang bentuknya memang murni lisan. Yang termasuk ke dalam kelompok ini adalah: a) bahasa rakyat, seperti: logat, julukan, dan sebagainyal; b) ungkapan tradisional, seperti: peribahasa, pepatah, pemeo; c) pertanyaan tradisional, seperti: teka-teki; d) puisi rakyat, seperti: pantun, gurindam, syair; e) cerita prosa, seperti: mite, legende, dongeng; dan f) nyanyian rakyat. Folklore Bukan Lisan adalah folklore yang bentuknya bukan lisan, walaupun cara pembuatannya diajarkan secara lisan. Kelompok ini dibagi menjadi dua, ialah a) material, seperti: arsitek rakyat, kerajinan tangan, pakaian, perhiasan, masakan, minumam, obat tradisi; dan b) Bukan Material, seperti: musik rakyat, gerak isyarat tradisional, bunyi isyarat komunikasi rakyat, dan sebagainya. Folklore Sebagian Lisan adalah folklore yang bentuknya merupakan campuran unsur lisan dan bukan lisan, misalnya: kepercayaan rakyat, permainan rakyat, teater, tarian, adat-istiadat, upacara, pesta, batu permata, dan sebagainya.

Menurut Iskandar (2008), bahwa teknik pengumpulan data dapat dilakukan oleh peneliti melalui beberapa cara. Dapat melalui teknik observasi, wawancara, maupun kuesioner. Sementara menurut Ghony dan Almanshur (2012) bahwa teknik pengumpulan data data dilakukan dengan menggunakan teknik observasi, wawancara, dan teknik dokumen. Sehubungan dengan hal tersebut maka teknik pengumpulan data pada penelitian ini peneliti menggunakan teknik wawancara dan dokumen. Berkaitan dengan pengumpulan data ada beberapa kesulitan yang peneliti alami di lapangan. Pertama, peneliti agak sulit menemukan nara sumber yang betul-betul menguasai bentukbentuk Folklore yang masih hidup dan berkembang dalam masyarakat kabupaten
Lingga. Kebanyakan penutur asli Folklore yang betul-betul menguasai sudah wafat. Kalaupun juma beberapa orang itupun mereka hanya menguasai dan mampu menuturkan sebagian saja. Setiap desa atau kelurahan hanya menguasai di kelurahannya saja. Oleh sebab itu, peneliti harus turun ke setiap kelurahan dan kecamatan yang ada di kabupaten Lingga.

Analisis data yang peneliti lakukan dalam bentuk analisis isi (conten analysis). Bentuk analisis konten dalam bidang ilmu sastra khususnya Folklore pada dasarnya merupakan upaya peneliti untukmenangkap isi yang terkandung dalam karya sastra, khususnya Folklore. Menurut Endraswara (2011), "Analisis konten juga merupakan analisis isi karya sastra dari aspek ekstrinsik, yang meliputi: analisis nilai moral/etika, nilai pendidikan, nilai filosofis, nilai relegius, dan nilai kesejarahannya". Namun, dalam hal ini analisis data terhadap isi Folklore peneliti lakukan dalam bentuk analisis: (a) nilai agama, yaitu ajaran Islam, (b) budi-pekerti, (3) sosial, (4) kerja keras, dan (5) nilai pendidikan. Nilai-nilai tersebut sebagaimana terkandung dalam Gurindam Dua Belas Karya Raja Ali Haji.

\section{Hasil dan Pembahasan}

Hasil penelitian yang telah peneliti peroleh berkaitan dengan bentuk-bentuk Folklore masyarakat kabupaten Lingga adalah folklore yang berbentuk lisan, bukan lisan, dan folklore sebagian lisan. Dalam bentuk Folklore lisan, meliputi: (1) bahasa rakyat; (2) ungkapan tradisional: pribahasa, pepatah, pameo; (3) pertanyaan tradisional; dan (4) cerita proses: mitos, yaitu Gunung Daik Bercabang Tiga, Orang Bunian Gunung Daik, Asal Mula Nama Dabo_Singkep, Meriam Tegak, Orang Bunian Pulau Selayar, Perigi Hang Tuah, Kampung Nerekeh, Asal Mula Nama Daik, Asal Mula Nama Sei besar, Kajang Lipat, Ratib Saman, dan Bersih Tembuni; dan legenda, yaitu: Pulau Pilang, Pulau Alut, Tanjungmana, Tanjungbungsu.

Untuk Folklore sebagian lisan, seperti: (1) permainan rakyat, yaitu: gasing, layang- 
layang, guli, jong, silat perkawinan, permainan basung, Engklek, Buah Pare, Ambung Gile, dan permainan Enggrang; (2) Teater Rakyat: Teater Bangsawan, (3) Tarian Rakyat: tari Merawai dan Jiget Dangkong; (4) adat-istiadat: adar perkawinan, tabor beras-kunyit, kain lipat 44; (5) Upacara Adat: kelahiran bayi, mandi syafar; Folklore bukan lisan: a) material: arsitek rakyat: (1) arsitek rumah adat Melayu Lingga; (2) kerajinan tangan: kain telepuk, tudung manto; (3) pakaian tradisional: songket, tanjak, keris, baju kurung, baju gunting cina, peci, dan kain dagang; (4) makakan tradisional: kepurun, tepung gomak, roti belauk; (5) minumam tradisional: Air Dohot es air mata bunda/mentimun, aie serbat, kopi malang, laksamana mengamuk. es sari rumput laut, kopi hawai, kopi kelapa, kopi o, kopi rosella, kopi tarik, sirup bakau, sirup limau; (6) obat tradisi: akar-akar herbal. (7) Alat musik tradisional: Kompang: Biola,Gambang Mentuda, tamborin, gambos, gendang, serunai, dan kerincing; (3) Jenis Musik Tradisional Melayu: Musik Pantai Mempanak, Musik Pancur, Musik Damnah, Musik Gugusan Ulau Senayang, Musik Joget Bekawan, Musik Moto Selogan Lingga Bertuah, Musik Pahlawan Penube, Gurindam Lingga.

Pada kesempatan ini peneliti akan mengungkap nilai-nilai kearifan lokal yang terkandung dalam mitos Orang Bunian Gunung Daik dan Orang Bunian Pulau Selayar.

Kerangka teori yang digunakan dalam analisis dan pembahasan nilai kearifan lokal Folklore masyarakat Kabupaten Lingga ini adalah teori yang telah dikemukakan Endraswara (2009), yaitu: (1) Folklore yang berkaitan dengan kesejahteraan dan (2) Folklore yang berkaitan dengan kedamaian. Folklore yang berkaitan dengan kesejahteraan mengandung beberapa nilai kearifan lokal meliputi: nilai (a) kerja keras, (b) disiplin, (c) pendidikan, (d) kesehatan, (e) gotong royong, (f) pengelolaan gender, (g) pelestarian dan kreativitas budaya, (h) peduli lingkungan. Folklore yang berkaitan dengan kedaiaman, mengandung nilai kearifan local meliputi: (a) kesopansantunan, (b) kejujuran, (c) kesetiakawanan sosial, (d) kerukunan dan penyelesaian konflik, (e) komitmen, (f) pikiran positif, dan nilai (g) rasa syukur.

\section{B.1 Mitos Orang Bunian Penghuni Gunung Daik}

B.1.1 Mitos Sebagai Media Peningkatan Kesejahteraan Rakyat, memiliki nilai kearifan lokal:

(1) Nilai Disiplin

Mahluk halus (orang Bunian penghuni Gunung Daik) memiliki sikap disiplin yang tinggi. Buktinya setelah beberapa peralaratan mereka digunakan oleh masyarakat sekitar tidak dikembalikan maka mereka murka. Sejak itu mereka tak percaya lagi kepada masyarakat. Masyarakat tak bisa lagi meminjam peralatan mereka untuk pesta. Harusnya kita sebagaimanusia yang terhormat memiliki sikap disiplin sebagaimana yang mereka perlihatkan. Inilah sebuah pembelajaran yang perlu kita ambil hikmahnya, yaitu hidup harus disiplin agar dapat menjadi manusia yang dipercaya.

\section{(2) Nilai Pendidikan}

Nilai pendidikan yang terkandung dalam mitos Orang Bunian Penghuni Gunung Daik adalah jangan menjadi manusia yang tidak jujur. Jadilah manusia yang jujur dan dapat dipercaya. Jika kita meminjam segala sesuatu maka setelah masanya dating kembalikanlah kepada yang empunya. Jangan menjadi manusia yang pendusta karena itu tidak baik.

(3) Nilai Gotong Royong

Nilai kearifan lokal yang terkandung dalam mitos Orang Bunian Penghuni Gunung Daik adalah ternyata ternyata dulunya orang Bunian penghuni Gunung daik suka bergotong royong dengan masyarakat sekitarnya. Mereka suka membantu masyarakat yang membutuhkannya. Mereka rela meminjamkan peralatan yang mereka miliki tanpa takut tidak dikembalikan. Ini membuktikan bahwa orang Bunian penghuni Gunung Daik dulunya suka bersosial. Orang Bunian penghuni Gunung Daik menjalin hubungan baik dengan masyarakat sekitarnya. 
B.1.2 Mitos Sebagai Media Peningakatan Perdamaian, memiliki nilai kearifan lokal, yaitu:

(1) Nilai Kejujuran

Orang Bunian penghuni Gunung Daik jelas sangat menjunjung tinggi nilai kejujuran. Mereka sangat suka dengan orang yang jujur. Begitu juga sebaliknya, mereka tidak suka dengan orang yang tidak jujur. Dari data yang peneliti peroleh ditemukan bahwa orang yang disukai orang Bunian untuk mereka ambil untuk dijadikan suami atau istri adalah orang-orang yang jujur. Laki-laki yang jujur atau perempuan yang jujur. Aspek kejujuran bagi mereka menduduki aspek yang sangat tinggi.

(2) Nilai Komitmen

Mitos orang Bunian penghuni Gunung Daik sangat memegang komitmen. Mereka tidak mau begitu saja meminjamkan peralatan mereka kepada anggota masyarakat yang akan melaksanakan pesta perkawinan tanpa ada komitmen dari anggota masyarakat yang melakukan pemimjaman (ada janji) bahwa alat yang dipinjam akan dikembalikan. Ternyata banyak anggota masyarakat yang melanggar komitmennya (tidak mengembalikan peralatan yang dipinjamnya). Akibatnya, sekarang orang Bunian penghuni Gunung Daik tak mau lagi mereka meminjamkan peralatannya kepada masyarakat lagi.

\section{B.2 Mitos Orang Bunian Pulau Selayar}

B.2.1 Mitos Sebagai Media Peningkatan Kesejahteraan Rakyat, memiliki nilai kearifan lokal:

\section{(1) Nilai Kerja Keras}

Orang Bunian Pulau Selayar sejak dulu sangat terkenal sebagai pekerja keras. Untuk memenuhi kehidupannya mereka kerja keras mengarungi lautan dengan kapal layarnya menangkap ikan. Mereka bukan orang yang begitu saja pasrah dengan kehidupannya. Sekembalinya mereka dari berlayar, mereka selalu menjemur layar perahunya di atas pohon Tembesu. Makanya mengapa pulau ini bernama Pulau Selayar tidak lain karena dulunya sering dilihat dari kejauahan adanya layar yang dijemur di atas pohon Tembesu.

(2) Nilai Disiplin

Orang Bunian Pulau Selayar merupakan orang-orang yang berdisiplin. Disiplin dalam hidup. Kapan harus istirahat dan kapan harus bekerja. Salah satu bukti kedisiplinan mereka adalah mereka selalu sehabis melaut menjemur layarnya di atas pohon agar dapat dipakai lagi keesokan harinya. Selain itu, mereka juga sangat disiplin dengan lingkungan di mana mereka berada. Mereka tidak suka merusak lingkungan.

(3) Nilai Peduli Lingkungan

Dari mitos Orang Bunian Pulau Selayar jelas terlihat bahwa orang Bunian Pulau Selayar sangat peduli dengan lingkungan. Marahnya orang Bunian penghuni pulau Selayar kepada kelompok orang yang datang dari Palembang tidak lain karena mereka datang ke pulau Selayar dengan cara merusak lingkungan. Sementara mereka sudah ingatkan, jangan tebang Pohon Tembesu yang ada di Pulau Selayar ini, tetepai kelompok yang dating tidak mengindahkannya. Akibatnya mereka harus tanggung kesalahan mereka sendiri. Mereka meninggal setelah menebang pohon Tembesu.

B.2.2 Mitos Sebagai Media Perdamaian, memiliki nilai kearifan lokal: (1) Nilai Kesetiakawanan Sosial

Orang Bunian Pulau Selayar ternyata dulunya adalah orang yang suka bergaul (bersosial). Buktinya kedatangan 7 orang lelaki dari Palembang mereka sambut dengan baik. Bahkan mereka terima untuk tinggal beberapa hari di Pulau Selayar. Orang Bunian Pulau Selayar kemudian menjadi tidak suka karena mereka melihat prilaku 7 orang pendatang ini tidak baik. Mereka suka menebang pohon. Bahkan pohon yang tidak boleh ditebang mereka tebang juga. Inilah yang menyebabkan kemudian orang Bunian Pulau Selayar ini menjadi marah. 


\section{B.3 Mitos Meriam Tegak}

B.3.1 Mitos Sebagai Media Peningkatan Kesejahteraan Rakyat, memiliki nilai kearifan lokal:

\section{(1) Nilai Kerja Keras}

Tokoh Encik Nuh dan istrinya Encik Walek adalah dua tokoh pekerja keras. Mereka selalu bekerja keras untuk memenuhi kehidupan rumah tangga mereka. Encik Nuh dan Encik Walek keduanya saling bekerja sama. Jika Encik Nuh selalu bekerja mencari nafkah di luar rumah (sebagai nelayan) maka Encik Walek bekerja membantu suaminya dengan berkebun dan beternak ayam. Hal ini juga yang membuat kehidupan keduanya (Encih Nuh dan Encik Walek) bahagia. Bahkan di kampung itu kehidupan mereka lebih baik ketimbang lainnya.

\section{(2) Nilai Pendidikan}

Nilai pendidikan yang dapat diambil dari mitos Meriam tegak ini adalah bahwa kehidupan suami istri itu harus saling mendukung untuk memenuhi kebutuhan yang diperlukan. Jika suami berjuang di laut (sebagai nelayan) maka istri juga harus membantu berjuang di darat (berkebun dan berternak ayam). Selain itu, jangan melawan suami, bila tak suka lebih baik diam saja. Hal ini sebagaimana terlihat pada tokoh Cik Walek yang diam saja sewakt suaminya (Cik Nuh) mengatakan bahwa dirinya tak akan mampu memindahkan meriam itu.

\section{(3) Nilai Gotong Royong}

Cik Nuh dan Cik Walek adalah dua tokoh yang saling bekerja sama dalam memenuhi kebutuhan rumah tangganya. Cik Nuh tak pernah memaksa istrinya untuk bekerja, hanya Cik Walek yang ingin membantu suaminya. Oleh sebab itu, keduakeduanya bekerja dengan senang hati tanpa paksaan.

(4) Nilai Pengelolaan Gender

Sebetulnya Cik Nuh dan Cik Walek sangat menjunjung tinggi gender. Cuma saja di saat Cik Nuh tak mampu memindahkan meriam yang ada di depan rumahnya ke tempat lain lidahnya terpeleset menyatakan bahwa istrinya tidak akan mampu memindahkan. Hal ini wajar saja, karena dalam pandangan masyarakat umum lelaki itu lebih kuat ketimbang wanita. Namun memang ada juga sebagian wanita yang mampu melakukan pekerjaan seperti lelaki. Kalaupun itu ada pasti orang-orang mengatakan wanita ini laksana lelaki. Memang wanita itu selalu diidentikkan dengan sosok yang lemah.

Cik Walek dalam mitos ini dikatakan mampu memindahkan meriam yang ada di halaman rumahnya ke tepi laut setelah dirinya memakan cendawan yang tumbuh di bawah lesung kayu. Tenaga Cik Walek tibatiba menjadi besar dan kuat sehingga mampu memindahkan meriam yang ada. Dalam hal ini jelas ada kekuatan gaib yang membantu Cik Walek.

(5) Nilai Peduli Lingkungan

Ada beberapa alas an dalam mitos Meriam Tegak ini mengapa Cik Walek meminta suaminya (Cik Nuh) untuk memindahkan meriam yang ada di halaman rumahnya. Pertama, posisi letak meriam itu yang sangat merusak keindahan halaman rumah. Kedua, meriam itu telah memakan korban, yaitu anak ayam kejepit di dalamnya hingga mati. Kedua sikap tersebut jelas sangat berkaitan dengan kepedulian Cik Walek dengan lingkungan tempat tinggalnya.

B.3.2 Mitos Sebagai Media Perdamaian, memiliki nilai kearifan lokal:

(1) Nilai Kesopansantunan

Keluarga Cik Nuh dan Cik Walek adalah keluarga yang penuh sopan santun. Lihat saja bagaimana tutur kata yang diperlihatkan Cik Nuh kepada istrinya (Cik Walek). Begitu juga tutur kata CikWalek dengan suaminya (Cik Nuh). Peneliti tidak menemukan diksi yang tidak sopan. Tutur kata mereka penuh dengan tata kesopanan.

(2) Nilai Kesetiakawanan Sosial 
Rumah Cik Nuh selalu dikunjungi orang-orang. Mulai dari orang yang hanya mendengarkan ucapan Cik Nuh hingga orang-orang yang datang untuk meminta pertolongan penyembuhan dari berbagai penyakit. Rumah Cik Nuh selalu ramai dikunjungi warga. Inilah bukti bahwa Cik Nuh sangat menjunjung tinggi kesetetiakawanan social.

\section{B.4 Mitos Asal Mula Kampung Nerekeh}

B.4.1 Mitos Sebagai Media Peningkatan Kesejahteraan Rakyat, memiliki nilai kearifan lokal: (1) Nilai Pendidikan.

Nilai pendidikan yang dapat diambil dari mitos asal mula Kampung Nerekeh ini adalah jadi pemimpin tidak boleh zalim. Allah sesungguhnya tidak suka kepada pemimpin yang zalim. Raja Fulan jelas adalah raja yang zalim. Raja ini zalim kepada rakyatnya sendiri. Akibatnya Allah murka dan mengutus seorang pemuda pemberani ke istana Raja Fulan dan membunuhnya. Jadilah pemimpin yang selalu mengayomi rakyat agar menjadi pemimpin yang disenangi rakyat. Bukankah tugas seorang pemimpin itu adalah melindungi rakyat bukan menyiksa rakyat.

B.4.2 Mitos Sebagai Media Perdamaian, memiliki nilai kearifan lokal:

(1) Nilai Kerukunan dan penyelesaian konflik

Raja Fulan jelas merupakan raja yang tidak menyelesaikan masalah, melainkan menciptakan masalah. Memperlakukan rakyat secara kejam jelas akan menimbulkan banyak masalah. Bahkan rakyat akan membencinya. Sikap Raja Fulan jelas merupakan sikap yang tidak patut ditiru.

\section{(2) Nilai Rasa Syukur}

Rakyat sangat bersyukur atas kepatian

Raja Fulan dan berterima kasih kepada pemuda pemberani yang telah membunuh raja mereka yang zalim. Rakyat yang tadinya merasakan negeri mereka sebagai neraka (Nerekeh) kini menjadi sebaliknya. Rakyat sangat beryukur kepada Allah sang Maha
Pencipta karena telah mengutus seorang pemuda pemberani ke negeri mereka.

\section{Simpulan}

Berdasarkan hasil analisis data yang telah diperoleh dapat peneliti simpulkan bahwa Folklore Masyarakat kabupaten Lingga kaya akan nilai-nilai kearifan lokal di dalamnya. Hal ini diketahui mulai dari nilai yang bernilai kesejahteraan hingga nilai-nilai kedamaian. Dengan demikian, nilai-nilai ini perlu dan layak diaplikasikan dalam kehidupan sehari-hari terutama untuk generasi muda sebagai upaya pelestariannya.

\section{Daftar Rujukan}

Angesti, A. J. A. (2013). Tradisi Gapura Masjid Wali di Desa Loram Kudus. Piwulang: Jurnal Pendidikan Bahasa Jawa, 1(1).

Danandjaja, J. (1991). Folklor Indonesia: Ilmu gosip, dongeng, dll. Jakarta: PT Grafiti.

Endraswara, S. (2011). Metodologi Penelitian Sosiologi Sastra. Jogjakarta: CAPS.

-----. (2009). Metodologi Penelitian Folklore: Konsep, Teori, dan Aplikasi: Yogyakarta: MedPress.

Ghony, M. D., \& Almanshur, F. (2012). Metodologi penelitian kualitatif. Jogjakarta: Ar-Ruгz. Media, 61.

Ilminisa, R. R. (2016). Rekayasa kreatif cerita anak bermuatan pendidikan karakter berdasarkan folklor lisan di Jombang (Doctoral dissertation, Universitas Negeri Malang).

Iskandar. (2008). Metodologi Penelitian Pendidikan dan Sosial (Kuantitatif dan Kualitatif). Jakarta: Gaung Persada Press.

Marwati, A. (2015). Ungkapan Tradisional Dalam Upacara Adat Perkawinan Masyarakat Bajo Di Pulau Balu Kabupaten Muna Barat. Jurnal Humanika, 3(15).

Nursa'ah, K. (2014). Inventarisasi Cerita Rakyat di Kabupaten Banjarnegara. Sutasoma: Jurnal Sastra Jawa, 3(1). 
Pudentia, MPSS. (2015). Metodologi Kajian Tradisi Lisan. Jakarta: Yayasan Obor Indonesia dan Yayasan Asosiasi Tradisi Lisan.

Rachman, D. (2012). Kajian mitos masyarakat terbadap foklor Ki Ageng Gribig (Doctoral dissertation, Universitas Negeri Malang).

Suhardi, S., \& Riauwati, R. (2017). Analisis nilai-nilai budaya (melayu) dalam sastra lisan masyarakat kota tanjungpinang. Lingua, 13(1), 25-33.

Suhardi. (2019). Nilai Kearifan Lokal Folklore Masyarakat Kabupaten Bintan. Diakses dari: http://sasando.upstegal.ac.id/index.ph $\mathrm{p} /$ sasando/article/view/67.

Sukmawan, S., \& Nurmansyah, M. A. (2014). Etika Lingkungan dalam Folklor Masyarakat Desa Tengger. LITERASI: Indonesian Journal of Humanities, 2(1), 8895. 